DISERTACIJE - DISSERTATIONS

\title{
RAZVOJ I OBLICI GLAGOLJAŠKOG PJEVANJA U SJEVERNOJ DALMACIJI
}

The Development and Forms of the Glagolitic Chant in Northern Dalmatia

$$
\text { Jerko B ezić }
$$

Svojevrstna posebnost ljudske glasbene kulture v primorski Hrvatski je tamkajšnje tradicionalno cerkveno ljudsko petje, liturgično in paraliturgično. Do leta 1965 je bilo delno $\mathrm{v}$ cerkvenoslovanskem, delno $\mathrm{v}$ arhaiziranem živem hrvatskem jeziku. Namen disertacije je bil prikazati razvoj tega petja, »glagoljaškega petja « v severni Dalmaciji od njegovih začetkov $\mathrm{v} 10$. stoletju do današnjih dni.

Termin »glagoljaško petje označuje ljudsko cerkveno petje (zborno in solistično), ki je izšlo iz liturgičnega petja $v$ staroslovanskem jeziku in $v$ cerkvenoslovanskem hrvatske redakcije, se postopoma formiralo $\mathrm{v}$ liturgično petje zahodnega obreda pretežno $\mathrm{v}$ živem hrvatskem jeziku, a napeve oblikovalo po elementih gregorijanskega korala in karakteristikah posvetnega ljudskega petja tistih geografskih področij, na katerih se je razvijalo.

V izčrpnem pregledu literature, ki se je doslej bavila samo z glagoljaškim petjem izven področja severne Dalmacije, je avtor disertacije podrobno vrednotil njene zaključke, še posebej predpostavke o glagoljaškem petju v preteklih časih (E. Koschmieder, V. Žganec).

Osrednje poglavje disertacije skuša rekonstruirati razvoj glagoljaškega petja. Obsega več podpoglavij, v katerih je govor o pojavi glagoljaškega petja v 10. stol. in njegovem razvoju do sredine 13. stol., o razvoju od prvega omejevanja v Zadru (1460) do tridentinskega koncila, o odmevih tridentinskega koncila, o glagoljaškem petju od nastopa nadškofa Zmajevića do druge avstrijske vladavine (1713-1813) in za časa te vladavine $\mathrm{v}$ razdobju od 1813 do 1918. Za rekonstrukcijo glagoljaškega petja skozi posamezna razvojna razdobja avtor disertacije na splošno ni imel na voljo ustreznega konkretnega gradiva, ki zaradi ustnega predajanja ni obstajalo $\mathrm{v}$ pisani formi. Zato se je $\mathrm{v}$ glavnem moral nasloniti na splošne zgodovinske vire. Za razdobja od 16. stol. dalje, zlasti pa za 18. in 19. stol. si je indirektno pomagal tudi s starejšimi še živimi napevi iz obilnega terenskega gradiva, ki ga je zbral v letih 1958-1964 v severni Dalmaciji na teritoriju zadrske nadškofije (npr. velikonočna sekvenca v obliki stalnega dialoga, starinske pogrebne pesmi).

Iz tako rekonstruiranega razvoja je avtor disertacije na temelju dostopnega gradiva skušal pokazati da je glagoljaško petje v drugi polovici 14. stol. in v prvi polovici 15. stol. bilo $\mathrm{v}$ Zadru in $\mathrm{v}$ njegovem zaledju zelo verjetno pod precejšnjim vplivom zadrskih variant rimskega koralnega petja. Po tridentinskem koncilu glagoljaši niso dọbili možnosti za kvalitetno šolanje. V zelo težkih življenjskih pogojih 
se niso posebej bavili z liturgičnim petjem. Direkten vir iz sredine 18. stol. pa že poroča o neposrednem sodelovanju številnih laikov, ljudskih pevcev $\mathrm{v}$ liturgičnem petju. Na temelju starejših slojev danes živih oblik glagoljaškega petja sklepa avtor disertacije, da je $\mathrm{v}$ tem času prišlo do pomembnega vdora elementov posvetnega petja $v$ liturgično glagoljaško petje.

O živih oblikah glagoljaškega petja $\mathrm{v}$ prvi polovici 20. stol. disertacija daje samo informativen pregled. Razporeja jih po vsebini in funkciji teksta (liturgično petje, paraliturgično petje in péte molitve) in po glasbenih elementih (tonalni odnosi, ritem, večglasje).

Priloženih 40 notnih primerov je avtor disertacije izbral glede na skupne značilnosti in specifične karakteristike. Prvi primeri prikazujejo značilnosti večjega dela napevov iz severne Dalmacije, drugi pa se zaradi starosti ali novejše razvitejše oblike vidno izdvajajo iz ostalih oblik.

Obranjena dne 18. aprila 1970 na filozofski fakulteti univerze v Ljubljani.

A specific trait of folk music culture in the coastal region of Croatia is the traditional folk chant, both liturgical and paraliturgical. Up until 1965 it was performed partly in Old Church Slavonic and partly in an archaic but still living Croatian language. The aim of the dissertation was to show the development of this chant, the so-called »Glagolitic chant« in northern Dalmatia from its beginnings in the $10^{\text {th }}$ century up to the present day.

The term »Glagolitic chant « denotes a folk chant (solistic and choral), descended from the chant in Old Slavonic and in a Croatian version of Old Church Slavonic, which was then gradually formed into a liturgic chant of a Western rite, sung predominantly in a living Croatian language, whereby the melodics were modelled on the elements of the Gregorian chant and the secular folk song of the areas where it developed.

In an exhaustive survey of the literature which until now dealt only with the Glagolitic chant outside the area of northern Dalmatia, the author evaluated in detail the conclusions of this literature and especially the surmises about this chant in the past, forwarded by such authors as E. Koschmieder and V. Žganec.

The central chapter of the dissertation attempts to reconstruct the development of the Glagolitic chant. It contains many sections in which the author discusses its appearance in the $10^{\text {th }}$ century and its development up to the middle of the $13^{\text {th }}$ century, the development from its first restriction in Zadar (1460) to the Council of Trent, the consequences of this council, the Glagolitic chant from the accession of Archbishop Zmajevic to the beginning of the period of the second Austrian rule i. e. from 1713 to 1813 and during this rule from 1813 to 1918. For the reconstruction of the chant through its separate phases there was in general no concrete material available, owing to its oral tradition. Therefore the writer had mainly to rely upon general historical sources. For the period from the $16^{\text {th }}$ century on and especially for the 18th ind 19th centuries, older, still living melodies also included in the extensive material he recorded from 1958 to 1964 in northern Dalmatia within the archbishopric of Zadar (e. g. Easter sequence in the form of a continuous dialogue, ancient funeral songs) were of help to him. 
On the basis of this reconstructed development and the material available, the author attempted to explain that the Glagolitic chant in the second half of the 14th century and the first half of the 15th century in Zadar and its surroundings was probably under a rather strong influence of Zadar versions of the Roman chant. After the Council of Trent the adherents of the Glagolitic chant had no good opportunities for an appropriate training, and under such difficult conditions they were unable to devote themselves to it. However, a direct source from the middle of the $18^{\text {th }}$ century gives us evidence of the direct participation of numerous laymen and folksingers in the liturgical chant. On the basis of older strata, still extant, of the forms of the Glagolitic chant, the author infers that in this time an extensive invasion took place of the elements of secular song into the liturgical glagolitic chant.

The dissertation only gives an informative survey of the still living forms of this chant in the first half of the 20th century. They are ordered according to the contents and function of the text (liturgical chants, paraliturgical chants and sung prayers) and according to their musical elements (tonal relations, rhythm, polyphony).

The 40 musical examples included were chosen on a basis of common characteristics and on the grounds of specific characteristics. In the first case they show the characteristics of a greater part of tunes from northern Dalmatia, while in the second case they obviously differ from the other forms owing to their ancient or newer, more developed style.

Defended April 18, 1970, University of Ljubljana. 